\title{
The Analysis of Accounting Policy Choice Based on Tax Planning
}

\author{
Qiong Yu \\ Yunnan College of Business Management, China
}

Keywords: tax planning, accounting policy, finance, accounting management

\begin{abstract}
The establishment of a corporate financial management system is inseparable from tax planning, and the social environment and economic environment in which enterprises are located today create possibilities for corporate tax planning. In essence, corporate tax planning plays a vital role in corporate financial management. In the work of corporate tax planning, it is necessary to always adhere to the overall financial management objectives as the basic principle, and fundamentally play the function of tax planning. This paper starts with the relationship between the choice of accounting policies and tax planning, finds out the factors affecting the choice of accounting policies of enterprise managers, and finally summarizes the impact of tax planning on the choice of accounting policies.
\end{abstract}

\section{Introduction}

In economic activities, for enterprises, the pursuit of profit maximization is undoubtedly the driving force and purpose of its development. However, China's taxation is taken from the people. The nature of the people and the characteristics of compulsory, unpaid, and fixed nature determine that taxation is not only an obligation of the enterprise, but also an important part of the enterprise's operation according to law [1]. Therefore, how to balance the minimization of tax and the maximization of profits is especially important for enterprises. Reasonable and effective tax planning can help companies achieve tax savings without violating the law. Then, the choice of accounting policies closely related to it is the most important part of the tax-saving link.

\section{Overview of tax planning}

\subsection{The meaning of tax planning.}

Tax planning refers to the taxpayer or its agent consciously using the comprehensive knowledge of taxation, accounting, law, finance, etc., and adopting reasonable legal or "non-illegal" means to reduce tax costs and improve corporate interests [1]. Maximize economic behavior. The content of tax planning mainly includes five aspects: tax avoidance, tax saving, transfer planning, avoiding tax traps and realizing zero risk related to taxation. Tax avoidance refers to the taxpayer's use of non-violation means, using the blanks and loopholes in the tax law to obtain tax benefits. This method is neither illegal nor legal, and is very different from tax evasion. Taxpayers need to conduct in-depth research on the current tax law in the process of tax avoidance planning to find out the loopholes. Tax saving refers to the taxpayer's various preferential policies in the tax law, such as the threshold, tax and fee reduction policies, so as to plan the production and business activities of their own enterprises, reducing the taxes and fees that enterprises must pay. This kind of tax planning activity is an effective method of reducing taxes and fees. It is adopted by many companies at this stage [1]. The transfer planning refers to a series of measures to reduce the tax burden of the company, such as adjusting the price of the goods, and transferring the taxes and fees that should be paid to others. Avoiding tax traps means that taxpayers in the course of their operations must pay special attention to the provisions of tax policies that are considered tax traps and avoid falling into them. Tax-related zero risk refers to taxpayers who have a clear understanding of the tax they are required to pay in production and operation. When reporting tax, they must be timely and full. In the event of tax payment, it is necessary to avoid violations. phenomenon. 


\subsection{Tax planning characteristics.}

There are five main characteristics of tax planning: First, the legality of tax planning. Legitimacy refers to the choice of taxpayers in their optimization of various taxation schemes. This is also the most basic feature of tax planning. It is not only in line with the provisions of the national tax law, but also in line with the state's willingness to formulate tax laws. Second, the policy orientation of tax planning refers to the role that the state can guide the behavior of taxpayers through various tax incentives, and to achieve the state's macroeconomic regulation and control services [2]. The third is the purpose of tax planning. It refers to the various methods and business activities selected in the process of tax planning for effective financial management, maximizing corporate value and maximizing the interests of corporate shareholders. . Fourth, the professionalism of tax planning refers to the full understanding of the current taxation policy in the process of tax planning, professional accounting knowledge, optimization of various business activities of the enterprise, and the formation of the optimal plan. , saving tax costs. The fifth is the timeliness of tax planning [2]. It means that the taxation policies and tax laws of the country are constantly changing in different periods. In the face of such changes, taxpayers must adjust their behaviors in a timely manner and adopt the current tax laws. Strategy to achieve the purpose of reducing tax costs.

\section{The relationship between tax planning and accounting policy choice}

\subsection{Tax planning and accounting policy choices have a common theoretical basis.}

In 1986, Watts and Zimmermanlj pioneered the introduction of contract theory in economics into accounting research. In the social contract theory, the enterprise is regarded as the intermediary of the connection contract, and the point of connection is the interests of creditors, the government, the public, the shareholders' enterprise managers, the public and other parties [1]. These interests together constitute the compensation contract (between the enterprise and the public); the debt contract (business and enterprise, between the enterprise and the shareholders); and the political cost (between the enterprise and the government). All parties are striving to maximize the interests. In this process, the government is both the maker and executor of the tax policy and the maker of the accounting policy. It is equivalent to the parties to the contract, and the enterprise as the party obeying the contract. To maximize profits, we can only make tax planning and choose the appropriate accounting policies.

\subsection{Tax planning is one of the economic motives for accounting policy choices.}

For companies, the motivation for tax planning is to save taxes. The taxation of enterprises is directly related to the accounting report of the enterprise. It can be said that accounting is the executor and supervisor of the entire tax planning. Enterprises hope to pay less taxes without violating the law. Therefore, many companies have begun to make accounting policy choices [3].

\subsection{The choice of accounting policy is one of the means to achieve tax planning.}

The impact of accounting policies on taxation has two aspects: first, it is expressed in the choice of profit and loss and the choice of assets and liabilities; second, it is reflected in the time and place of determining the profit and loss of the enterprise and the adjustment of the accounting policy and accounting estimates to the profit and loss [3]. Of course, in both aspects, companies will choose the policy with the least amount of tax.

\subsection{Accounting policy choices and tax planning are subject to tax laws.}

In the process of tax planning and accounting policy selection, enterprises should implement the tax laws and regulations, and legally save taxes.

\section{Using tax planning to make accounting policy choices}

In the choice of accounting policies, the more commonly used methods of depreciation calculation 
of fixed assets, the choice of inventory pricing methods, and the choice of corporate sales settlement methods. These three aspects will be explained below:

\subsection{The choice of fixed asset conversion method.}

In China, there are special accounting standards: "When companies are depreciating fixed assets, the methods that can be used include: the workload method, the sum of years method, the double-declining balance method, the annual average method, etc.”. The depreciation of fixed assets of an enterprise is an important part of the cost of the enterprise. Different depreciation calculation methods will have different effects on the cost of the enterprise [4]. In China, average age depreciation is the method used by most companies, and accelerated depreciation is also used by some companies.

\subsection{The choice of inventory pricing method.}

The current tax law stipulates that enterprises should calculate their inventory pricing method according to their actual cost price and stipulate various calculation methods. Among these methods, the first-in first-out method, the moving average method, the weighted average method, the backward-in and the back-out method, and the individual valuation method are all relatively common [4]. However, companies should be aware that after deciding to choose a method, they are not allowed to change at will without special circumstances. At the same time, enterprises should choose the method of inventory pricing to fully consider the rising and falling prices of prices in the market, and then choose the appropriate method.

\subsection{The choice of the company's sales settlement method.}

The tax law stipulates that if the enterprise adopts direct receipt sales, the time for revenue recognition shall be the day when the payment is received or the claim is received, and the bill of lading is delivered to the buyer; if the goods are sold, the collection commitment is the entrusted bank's collection method, the income confirmation shall be the day when the goods are delivered and the collection procedures are completed; if the consignment is used, the time for the income determination shall be the day when the consignment list is received; if the goods are sold, if the sales and staging are used, For the payment method, the time for determining the income shall be based on the date agreed upon in the contract; and when the sales are received by the prepayment method, the realization of the income shall be confirmed when the goods are delivered [5]. Therefore, enterprises can choose the appropriate settlement method according to the way and strategy of their own product sales, determine the time for revenue confirmation, and reasonably plan the annual income to achieve the purpose of tax reduction.

\section{The specific application of tax planning in the choice of accounting policy}

\subsection{Tax planning in the financing process.}

Fundraising is a prerequisite for a series of business activities. The impact of financing behavior on business performance is mainly due to changes in capital structure. Whether the capital structure is reasonable not only restricts the size of the enterprise's risk, but also determines the tax burden and after-tax income of the enterprise to a considerable extent. Different financing methods will bring different expected income and tax burden to the company [5]. Corporate financing is generally divided into two types: debt financing and equity financing. Equity financing includes the use of retained profits and the issuance of new shares. It has the characteristics of low risk and high cost. Relatively speaking, debt financing is more tax-efficient and has the characteristics of high risk and low cost. Therefore, tax planning is not only useful in determining the capital structure, but also in determining the target of financing. Applying tax planning to a company's fundraising activities enables companies to find the best capital structure when determining funding costs.

\subsection{Tax planning in the investment process.}

In order to achieve the adjustment of the national productivity layout, the state will provide various 
tax incentives such as tax reduction and exemption for investment projects involving young and old, poor areas, special economic zones and bonded areas, and national industrial policies and national economic development plans [6]. Therefore, when selecting investment sites and investment industries, enterprises should fully consider the state's tax incentives for regions and industries, make full use of regional and industry tax incentives, and combine their own business characteristics to include themselves as much as possible. Within the scope, reasonable reduction of corporate tax burden, to obtain the maximum tax benefits. In terms of investment methods, corporate investment can be divided into direct investment and indirect investment. Generally speaking, since direct investment needs to consider the various taxes paid by enterprises, direct investment has more room for operation in tax planning than indirect investment.

\subsection{Tax planning in the business process.}

Since different depreciation methods will affect the cost and affect the profit of the enterprise, the enterprise should choose the appropriate depreciation method according to its own specific situation and choose the depreciation that can bring the maximum tax-saving effect to the enterprise. method. Generally speaking, at the same rate of tax rate, if the income tax rate has an upward trend, the straight-line method is used for depreciation; if not, the depreciation is accrued using accelerated depreciation [6]. Under the excess cumulative tax rate, depreciation is generally made using the straight-line method. Different inventory valuation methods will result in different ending inventory costs, which will affect the current profit. Therefore, when selecting the inventory valuation method, enterprises should consider the impact of price fluctuations and other factors to avoid fluctuations in profits due to cost fluctuations. In addition, the company's sales revenue varies according to the settlement method, and its revenue recognition and tax payment time are also different [5]. Through the choice of sales settlement method, the enterprise can adjust the income confirmation time and plan a reasonable income vesting year to achieve the purpose of delaying the payment of taxes.

\subsection{The choice of cost and expenses.}

In accounting, we should allocate the current cost and expenses as soon as possible, and estimate the possible losses, and use the accrued method to account for the amortization period of the cost as much as possible to achieve deferred tax time and get paid less income tax [6]. Tax benefits. In addition, the cost of sales, research and development, and technical renovation projects are also planned in the tax law.

\subsection{Tax planning in profit distribution.}

Since the company's previous annual losses can be compensated for by pre-tax profits within a certain period of time, enterprises should strive to make up for losses within the time limit and achieve the purpose of saving taxes. The profit distribution of enterprises is distributed in this way. According to the tax law, the cash dividends need to be taxed, and the stock dividends are tax-free [7]. Therefore, the company's stock dividends are beneficial to the company's capital turnover and reduce the shareholders' tax burden. . In addition, companies can also use stock repurchase instead of cash dividends, so that shareholders only need to pay taxes when they actually sell stocks and make profits, which is more favorable to shareholders, and can also adjust the shareholding structure and optimize capital for enterprises. The role of the structure. In short, companies should make tax planning based on actual conditions when distributing after-tax profits to help investors obtain higher net income after tax. Third, do a good job in tax planning and countermeasures

\section{Issues concerning the choice of accounting policies based on tax planning}

In actual work, wrong decisions often come from the distortion of information. Therefore, when tax planning is carried out, all aspects of economic information inside and outside the enterprise are indispensable for designing and selecting the best solution. This information includes the internal control management of the enterprise, the personnel system, the national guidelines and policies, and the application of accounting standards [7]. Only after fully collecting and analyzing different 
tax-related information, and processing and processing in time, can we form the best tax planning decision.

Tax planning is a legal act. It cannot violate the provisions of the tax law when accounting policies are selected, and it cannot violate the provisions of accounting policies. Therefore, tax planning for accounting policy selection should seek the space allowed by the tax law and accounting regulations. Taking into account the differences between tax laws and accounting policies, companies should pay attention to the choice of accounting policies should be selected by the tax law [7]. If the selected accounting policy is not allowed, the tax adjustment should be made on the basis of accounting profits. Therefore, although the accounting profit is reduced, once the tax adjustment is made, the taxable income is not reduced.

Among the many tax planning methods, the tax planning of accounting policy selection mainly uses two methods of narrowing the tax base and delaying tax payment. In addition to the impact of the time value of the capital, the deferred taxation method must also consider the changes in the tax environment and the actual operating conditions of the enterprise, and consider the use of other tax incentives.

Considering that the accounting policies of enterprises have not been arbitrarily changed, the choice of accounting policies should be based on a long-term perspective [7]. The choice of accounting policies should enable enterprises to pay the least tax or delay in taxation for a period of time, instead of only In a certain year, the tax burden is the least, so it is necessary to consider the long-term tax benefits of the company in the long run.

\section{Summary}

The tax policy changes rapidly, and it is constantly updated and revised according to the development of the society. If you pay attention to it, the regulations used may be outdated, and it may make us miss a good opportunity for tax planning. This requires planners not only to pay attention to the changing trend of taxation policies, but also to study tax laws, regulations, rules and regulations in a timely and systematic manner, master the details of tax laws, establish a tax information database, and constantly study the characteristics of economic development. Grasping the macroeconomic dynamics, reasonably anticipating taxation policies and their changes, scientifically and accurately grasping the spirit of tax law, especially understanding and understanding the various tax incentives, this is a basic link and an important link in tax planning.

In short, paying taxes according to law is the obligation of every enterprise, and the goal of business management is to maximize the benefits. While the enterprise understands and implements the tax regulations in a complete and accurate manner, it should find a scientific and reasonable balance point when the policy allows, and strive to reduce the cost of taxation and promote the sound operation of the enterprise.

\section{References}

[1] T.L. Chen, Tax planning and modern enterprise financial management, The Age of Riches, 2012, vol.2, pp.59-61.

[2] M.T. He, Accounting policy choice and tax planning, Cooperative Economy and Technology, 2007, vol.16, pp.23-25.

[3] Y.Ch.Yang, SMEs use accounting policies to choose tax planning proposals, administrative assets and finance, 2013, vol.19, pp.22-24.

[4] D.Y. Wang, Research on accounting policy choice based on tax planning, Economist, 2009, vol.6, pp.150-151.

[5] C.L. Wang, Corporate tax planning and accounting policy selection, Journal of Shandong Youth Management Cadre College, 2010, vol.11, pp. 17-20.

[6] L.L. Xu, Analysis of the impact of accounting policy choices on tax planning, Oriental Corporate 
Culture • Business Culture, 2011, vol.5, pp.43-46.

[7] R.Q. Liu, Studying the impact of tax planning on accounting policy choice, Times Finance, 2012, pp.89-91.

[8] H.T. Qiu, on tax planning and accounting policy choice, China Accounting Society Higher Schools Branch, 2009, vol.4, pp. 169-173. 